\title{
Colorectal Traditional Serrated Adenoma
}

National Cancer Institute

\section{Source}

National Cancer Institute. Colorectal Traditional Serrated Adenoma. NCI Thesaurus. Code C5674.

An adenoma that arises from the colon or rectum. It is characterized by prominent serration of the glands and the presence of generalized low-grade dysplasia. 